\title{
細胞分裂期において分裂期キナーゼが制御する染色体動態
}

\author{
栗原 大輔 1,2 \\ 1 名古屋大学大学院理学研究科 干 464-8602 愛知県名古屋市千種区不老町 \\ 2 JST ERATO 東山ライブホロニクスプロジェクト干 464-8602 愛知県名古屋市千種区不老町
}

\begin{abstract}
要旨 : 細胞周期の中でも細胞分裂期はダイナミックな染色体動態を伴う過程であり, その動態の美しさは古くから研 究者たちを魅了している，安定した遺伝情報の継承のために必須な染色体動態は，様々な分子が関わる精巧なメ カニズムによって制御されている，染色体分配に失敗すると直接異数染色体につながり，遺伝情報のバランスに狂 いが生じ, 細胞死やガン化を引き起こすため, 動物の研究では医薬の分野も含めて精力的に研究が行われているが, 植物ではほとんど明らかになっていない，著者らはこれまで，シロイヌナズナ，タバコを用いて染色体動態を制御す る分裂期キナーゼ，オーロラキナーゼの同定および機能解析を進めることによって，植物における染色体動態制御 機構を明らかにすることを進めてきた。本稿では, 近年次第に明らかになりつつある染色体動態の制御機構とともに， 植物における染色体動態研究の現状と展望を解説する.
\end{abstract}

\section{Mitotic kinases regulate chromosome dynamics during mitosis}

\author{
Daisuke Kurihara ${ }^{1,2}$ \\ 1 Graduate School of Science, Nagoya University, Furo-cho, Chikusa-ku, Nagoya, Aichi 464-8602, Japan \\ 2 Higashiyama Live-Holonics Project, ERATO, JST, Furo-cho, Chikusa-ku, Nagoya, Aichi 464-8602, Japan
}

Summary: During mitosis, chromosomes show dynamic movements. The orchestration of chromosome dynamics mediated by various molecules is required for stable transmission of genetic information. The failure of chromosome separation directly induces aneuploidy with imbalance of genetic information. Because aneuploidy, an abnormal number of chromosomes, and chromosome instability is found in most solid tumors, the mechanisms of chromosome dynamics are well studied in animals, specifically as therapeutic target. However, it remains to be unclear the mechanisms of chromosome dynamics with mitotic kinases in plants. The authors identified and analyzed Aurora kinases as mitotic kinases, which regulate chromosome dynamics during mitosis, in Arabidopsis thaliana and Nicotiana tabacum. In this review, I summarize the recent finding of the regulatory mechanisms of chromosome dynamics in animals and in plants, and discuss future perspectives.

Key words: cell division, chromosome dynamics, mitotic kinase, histone phosphorylation

\section{はじめに}

細胞分裂は，1つの細胞から2つの娘細胞へと遺伝 情報を均等に分配するという，生命の根幹をなす過程 である．もし遺伝情報が正確に，あるいは均等に分配 されないまま細胞分裂してしまうと，その娘細胞におい て遺伝情報のバランスに狂いが生じ，細胞死あるいは ガン化につながるなど，生命維持に深刻な結果を招く. 遺伝情報を正確かつ均等に分配するために，高等真 核生物のゲノムDNA は, 細胞分裂期に中期染色体と いう高度に凝縮した高次構造をとる. 細胞分裂期は夕゙ イナミックな染色体運動を伴う過程であり，その異常は 直接異数染色体や細胞死へと繫がるため, 綮密に制 御されなければならない.この制御に関わるタンパク質 として，分裂期キナーゼが挙げられる．分裂期キナー
ゼによる染色体動態の制御について，動物においては 詳細な分子メカニズムが明らかになりつつあるが，植物 においてはほとんど未知のままである。本稿では，細 胞分裂期における染色体動態について, 動物におけ る知見を紹介した後に，植物における現状について紹 介したい.

\section{細胞分裂期における染色体動態制御}

細胞分裂期は， $\mathrm{S}$ 期に複製された 2 組の姉妹染色分 体を，2つの娘細胞に正確に均等分配する過程である. 細胞分裂期に入ると，まず前期において染色体の凝 縮が始まる，そして核膜崩壊後，前中期において，染 色体は動原体で微小管と結合する.この紡錘体微小 管によって染色体は赤道面上へと移動し，中期におい 
て，すべての染色体の赤道面上への整列が完了した 後に，後期において，姉妹染色分体が両極へ分配さ れる.この過程において重要なことは，す心゙ての染色 体が適切に紡錘体微小管と結合し，そして赤道面上に 整列することである. これを達成するための機構が監視 機構であるM期チェックポイント，すなわちスピンドルチェッ クポイントである (Musacchio and Salmon 2007)．スピン ドルチェックポイントが監視しているのは次の 2 点である. 1つは, 動原体と紡錘体微小管が相互作用しているか. もう 1 点は，両極から紡錘体微小管によって動原体が引っ 張られることによる張力が発生しているかである．前中 期において，染色体はまず片方の動原体が片方の極 の紡鍾体微小管によって捕らえられる。この状態を“モ ノテリック結合”といい，一方向性結合であるといら(図 1A）。そしてもう片方の動原体が，反対の極の紡錘体 微小管に捕らえられ，二方向性結合となることによって， 染色体は赤道面上へと移動する(図1A). しかしながら， 動原体と紡鍾体微小管との結合はランダムに起きてお り，必ずしも二方向性結合とならず，しばしば異常な動 原体一微小管結合を生じる. 異常な動原体一微小管 結合には，両方の動原体が片方の極の紡錘体微小管 と結合する“シンテリック結合”と，片方の動原体に両極 の紡錘体微小管と結合する “メロテリック結合” の 2 種類 が存在する (図 1B)。この異常な動原体一微小管結合 は一方向性結合であるため，動原体と紡錘体微小管と の相互作用を監視するチェックポイントは解除するが, 張力を監視するチェックポイントは解除できない．この ような，張力を監視するチェックポイントに関わるタンパ ク質として，動物においてAurora Bキナーゼが挙げら れる (Carmena et al. 2009). Aurora Bキナーゼは姉妹 染色分体間のセントロメア周辺領域 (インナーセントロメ ア）に局在し，動原体に局在するタンパク質を少ン酸化 することによって，動原体一微小管結合を不安定化さ せている.しかしながら，二方向性結合となり動原体間 で張力が発生すると，動原体局在タンパク質とAurora Bキナーゼとの物理的距離が離れることによって，動原 体一微小管結合が安定化され，チェックポイントが解除 される(図1C)。近年, このチェックポイントは動原体が 伸展することによって解除されるともある (Uchida et al. 2009).

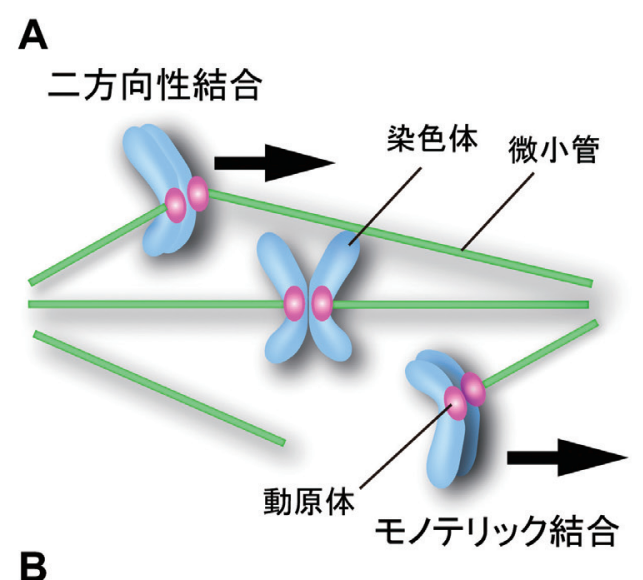

メロテリック結合

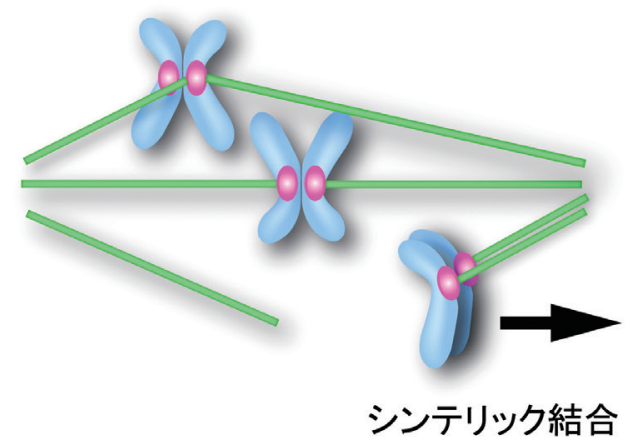

C

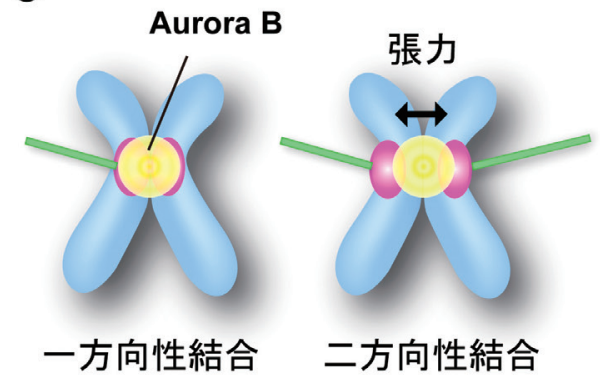

図 1 分裂前中期・中期における動原体一微小管結合様式と 染色体動態

(A) 分裂前中期・中期における染色体整列。モノテリック結 合では極方向に染色体は移動するが，二方向性結合になる と赤道面一移動する。（B) 染色体整列における異常な動原 体一微小管結合．シンテリック結合では極方向に染色体は移 動し，メロテリック結合では移動しない，(C) Aurora Bキナー ゼによる異常な動原体一微小管結合の校正。一方向性結合 では動原体間に張力が働いていないため，Aurora Bキナー ゼが動原体局在タンパク質をリン酸化し，動原体一微小管結 合を解除するが，二方向性結合となり動原体間に張力がか かると，動原体間の距離が離れ，Aurora Bキナーゼが動原 体局在タンパク質を少ン酸化できなくなり, 動原体一微小管結 合が安定化する.

\section{植物におけるオーロラキナーゼ}

このようにオーロラキナーゼは染色体動態に重要な 役割を担っているが，植物ではどのようになっているの 
であろらか：著者らはこれまで植物におけるオーロラキ ナーゼを同定し，その分裂期の染色体動態における機 能について解析してきたので紹介したい.

オーロラキナーゼは，酵母からヒトまで高度に保存さ れたセリン・スレオニンキナーゼであり，細胞分裂期開 始から細胞質分裂までの様々な過程において重要な役 割を担っている分裂期キナーゼである.動物のオーロラ キナーゼは，中心体や紡錘体極の制御，微小管の安 定性に関与するAurora A，染色体の凝縮，分離，動 原体一微小管結合，細胞質分裂を制御するAurora B, そして主に精巣で発現しAurora Bを相補しうるAurora Cが存在する．植物においてもオーロラキナーゼは保 存されており, シロイヌナズナArabidopsis thalianaに は3つのオーロラキナーゼ [AtAUR1, AtAUR2, AtAUR3 (Arabidopsis thaliana Aurora kinase)] が存在する (Demidov et al. 2005, Kawabe et al. 2005). AtAUR1 とAtAUR2 はキナーゼドメインにおいて $95 \%$ の相同性 を示し，AtAUR3とは65\%の相同性を示す，オーロラ キナーゼの一つの特徴として，ヌクレオソームを構成 するヒストンH3 Ser10をリン酸化 (H3S10ph) することが 挙げられるが, AtAURはin vitroにおいて3種類ともヒ ストンH3 Ser10のリン酸化能を有していた。またタバコ 培養細胞BY-2において GFP 融合タンパク質を用いて イメージング解析した結果，分裂期においてAtAUR1 とAtAUR2は紡錘体微小管に, AtAUR3は動原体に 局在しており，植物細胞においてもオーロラキナーゼ は細胞分裂期に重要な役割を担っていると考えられた (Demidov et al. 2005, Kawabe et al. 2005).

細胞内局在が明らかになる一方，細胞内における オーロラキナーゼの実際の機能は不明であった。タギ ングラインを用いた突然変異体解析を行おうとしたが, AtAUR3がハックアウトしているラインが得られなかった。 これはAtAUR3 が細胞分裂に重要なタンパク質であり, ハックアウトすると致死になってしまうためではないかと考 えられた。 そこで抗ガン剤として注目されていたAurora キナーゼ阻害剤であるへスペラジンを用いて, 解析を行っ た (Kurihara et al. 2006). ヘスペラジンはAuroraキナー ゼのATP結合部位に結合しリン酸化能を阻害するATP 拮抗阻害剂であり，動物細胞では効いていたが，植 物においてもAuroraキナーゼを阻害するかどうかは分 からなかった。まず植物においてAuroraキナーゼを阻 害するか確かめるために，タバコ培養細胞 BY-2 に添
加し, ヒストン H3 のリン酸化を免疫染色で調べたところ, H3S10phの免疫染色シグナルが減少したことより，へス ペラジンは植物においても Auroraキナーゼを阻害する ことが分かった（図 $2 \mathrm{~A} ， \mathrm{~B}$ )。ヘスペラジンによるオーロ ラキナーゼ阻害により，分裂中期において染色体は赤 道面上に整列したが，分裂後期において姉妹染色分 体の分離が遅れた遅延染色体が，また間期において 微小核と呼ばれる小さい核が多く観察された(図 2C, D).
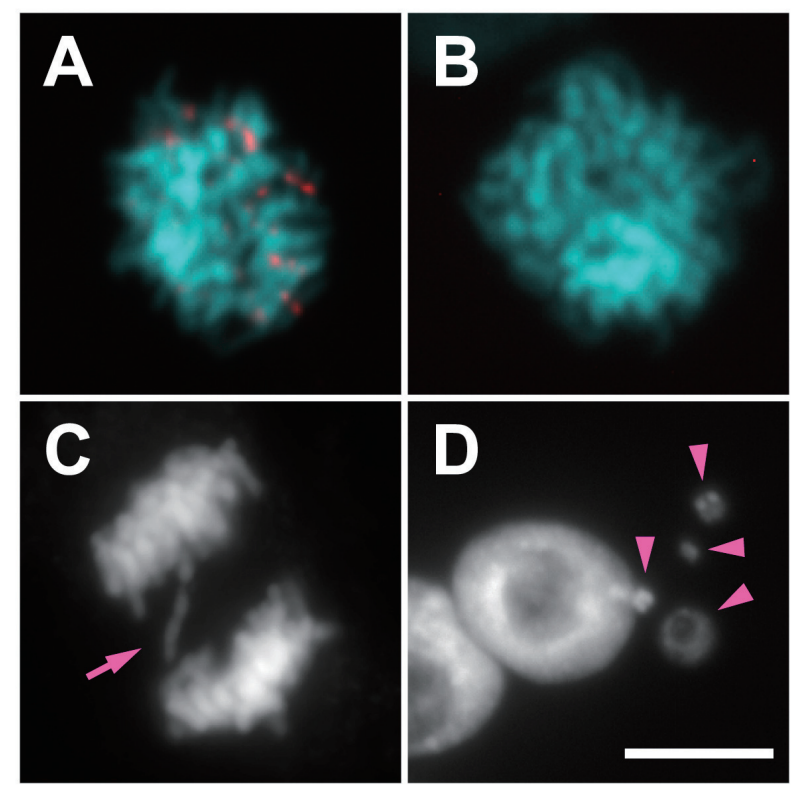

図 2 タバコ BY-2 細胞におけるオーロラキナーゼ阻害の影響

(A, B) 分裂前中期における抗 $\mathrm{H} 3 \mathrm{~S} 10 \mathrm{ph}$ 抗体 (赤)を用いた免 疫染色. DNAをDAPIで染色した (水色)。コントロール細胞 (A) ではセントロメア周辺領域にドット状のシグナルが観察さ れるが，へスペラジン処理細胞 (B) ではシグナルは顕著に減 少している。（C，D）オーロラキナーゼ阻害による染色体分離 異常. 分裂後期においては赤道面上に遅延染色体 (C, 矢印) が，間期においては通常の核よりも小さい微小核 (D, 矢じり) が観察された。 スケールバーは $10 \mu \mathrm{m}$.

さらに細胞分裂・染色体動態といったダイナミックな 現象におけるオーロラキナーゼの機能を解析するため に，蛍光タンパク質を用いたライブセルイメージングを 行うことによって動的な情報を得ることを試みた。まず 動原体をRFPおよび微小管をGFPによって可視化した タバコ培養 BY-2 細胞を確立した。ヘスペラジン処理し た形質転換 BY-2 細胞を用いてライブセルイメージング 解析した結果，動原体が赤道面上へ整列する時間が コントロールと比べて約 2 倍長くなった。また動原体の 挙動を追跡したところ，染色体は両極間を行ったり来た りしながら赤道面上へ整列していくが，ヘスペラジン処 
理細胞においては振動の速度が遅くなることが明らか になった。また細胞分裂後期において，片方の動原 体は正常に極に移動するが，もう一方は赤道面上に取 り残され，遅れて移動するといら動態と，両方の動原体 ともに赤道面上へ取り残され遅れて極へ移動するという 2 種類の遅延染色体動態が 1 つの細胞で同時に観察さ れた。赤道面上に取り残された片方の動原体は両極方 向へ伸展していたことより，この動原体では両極の紡錘 体微小管が結合しているメロテリック結合が起こっている と考えられる。このことは染色体整列時に観察された振 動速度低下の原因とも説明できる。すなわち，メロテリッ ク結合状態の動原体は赤道面方向への力がないために, この染色体では全体として赤道面方向への力が弱くなっ たため，振動速度が低下したと考えられる(図3A)。ま た両方の動原体が赤道面上で取り残されていた後者に おいては，ある程度の距離，両方の動原体は離れて いたことより，姉妹染色分体間の接着の解離が阻害さ れていることが考えられる(図 3B)。このようにオーロラ キナーゼ阻害剤を用いたライブセルイメージング解析 により，植物においてオーロラキナーゼは異常な動原 体一微小管結合の校正と姉妹染色分体間の接着の解 離を担うことによって，分裂前中期・中期における染 色体整列および分裂後期における姉妹染色分体の分 離といった染色体動態を制御していることが示唆された
(Kurihara et al. 2008).

シロイヌナズナにおいても，ヘスペラジン処理により 分裂期の H3S10ph が減少すること, そして遅延染色 体が観察されている (Demidov et al. 2009)。このように オーロラキナーゼを阻害することにより，染色体の不均 等分配が起こることから，植物においてオーロラキナー ゼが染色体動態に深く関わっていることが明らかとなっ た.これまでは培養細胞を用いて解析を行ってきたが， 植物体におけるオーロラキナーゼの役割はどのようであ ろうか。シロイヌナズナにおいて，AtAUR1，AtAUR2， $A t A U R 3$ ともに根や花芽，花といった分裂活性の高い 組織で発現している (Demidov et al. 2005)。また単離 した胚を用いてへスペラジン処理しライブセルイメージ ング解析した結果，染色体整列が完了する前に分配が 始まり分裂期が終わってしまう異常が観察された (栗原 ら，未発表)ことより，シロイヌナズナ植物体でもオーロ ラキナーゼは分裂期において染色体動態を制御してい ることが考えられる．興味深いことに，AtAUR2にはキナ一 ゼドメインの一部をコードする第 4 エキソンが久失したス プライシングバリアント $(A t A U R 2 S)$ が存在する (Kurihara et al. 2007)。精製AtAUR2S はin vitroにおいてH3S10 のリン酸化能は失っていたが，H3への結合能は有して いた.AtAUR2Sは葉，菱といった分裂活性の低い組織 で発現しており，GFP融合タンパク質はAtAUR2 と同じ

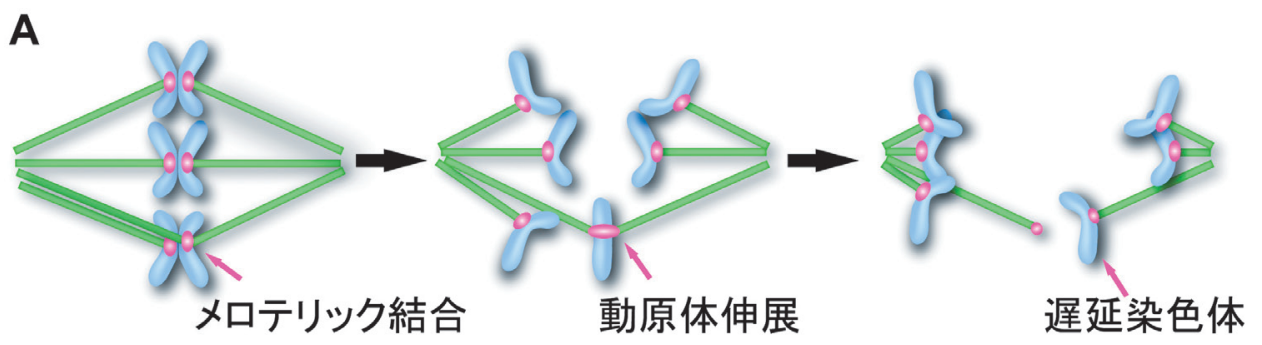

B

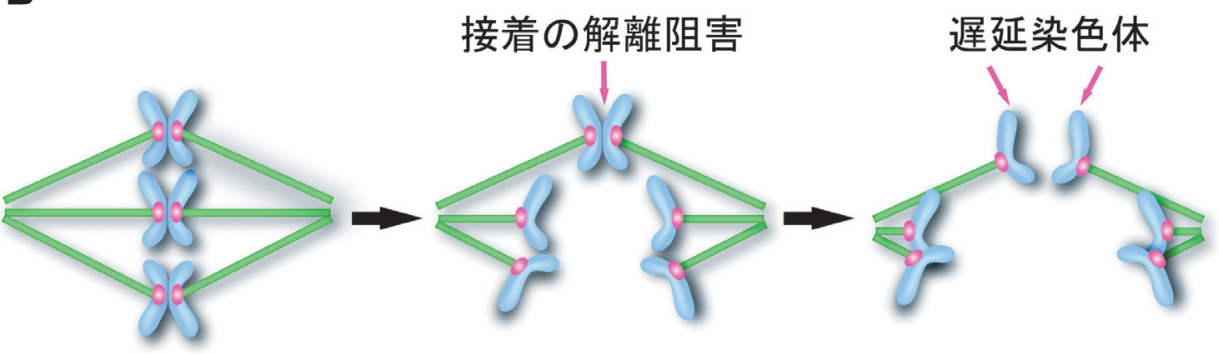

図 3 BY-2 細胞におけるオーロラキナーゼ阻害による遅延染色体形成モデル

BY-2 細胞におけるオーロラキナーゼ阻害の染色体分離異常には，メロテリック結合により片方 の染色体のみが極への移動が遅延し遅延染色体となる経路 (A) と接着の解離阻害により両方の 染色体ともに遅延染色体となる経路 (B) が考えられる. 
細胞内局在を示したことから, AtAUR2S はAtAUR2の コンペティターとして働き，細胞分裂しないようにしてい るといらメカニズムが示唆された (Kurihara et al. 2007). このようにオーロラキナーゼの染色体動態制御機構を 解析することによって, 植物における細胞分裂, 器官 形成メカニズムが明らかにされると期待される.

\section{分裂期キナーゼによるヒストン $\mathrm{H} 3$ リン酸化}

変わってこの章では, 分裂期キナーゼによって引き 起こされるヒストンリン酸化について紹介したい. 細胞分 裂期はダイナミックな染色体運動を伴う過程であり，そ のため高等真核生物のゲノムDNAは, 細胞分裂期に 中期染色体といら高度に凝縮した高次構造をとる。例 えば，ヒトでは $2 \mathrm{~m}$ の長さに達するDNAが直径 $10 \mu \mathrm{m}$ 程度の核内に収納されるが，そのような緻密な染色体 構造が形成されるメカニズムは未だ不明である. DNA は, ヒストン $\mathrm{H} 2 \mathrm{~A}, \mathrm{H} 2 \mathrm{~B}, \mathrm{H} 3, \mathrm{H} 4$ の 4 種類のヒストンタ ンパク質からなるヒストンコアに巻き付いたヌクレオソー ム構造をとっている.これらヒストンタンパク質の $\mathrm{N}$ 末端 はきちんとした立体構造をとらない直鎖上のヒストンテー ルと呼ばれ，このヒストンテール部分がリン酸化，アセ チル化，メチル化などさまざまな翻訳後修飾を受ける ことによってヌクレオソーム構造を変え，遺伝子発現な どがエピジェネティックに制御されることが知られている (Kouzarides 2007). ヒストン修飾の中でも，H3S10ph は酵母からヒトまで真核生物間で広く保存された細胞分 裂期特異的な修飾であり, リン酸化のタイミングが染色 体凝縮と強い相関を示すことより，古くから染色体構造 を制御する翻訳後修飾として注目されてきた(Bradbury et al. 1973, Marks et al. 1973, Gurley et al. 1975). 나 においては，G2 期後半からセントロメア周辺領域で始 まり, 細胞分裂期にはいると染色体周縁領域に広がり, 後期から減少し始め, 終期になると消失する (Goto et al. 2002). テトラヒメナのH3S10をアラニンに置換した 変異体では, 染色体凝縮と分離に異常が見られ (Wei et al. 1999)，またショウジョウバエにおいてRNAiによっ てAurora BキナーゼをハックダウンするとH3S10ph は消 失し, 染色体凝縮が阻害される (Adams et al. 2001). しかしながら, 出芽酵母のアラニン変異体では染色体 凝縮は正常に起こり (Hsu et al. 2000), Aurora Bキナー ゼを免疫除去したアフリカツメガエル卵抽出液で染色体 を形成させると, H3S10ph は消失するが，染色体凝縮
に異常は見られない (MacCallum et al. 2002) など，染 色体凝縮におけるH3S10phの役割については, 生物 種によって結果が違っており, 未だ統一した見解は得 られていない.

それでは植物におけるヒストンリン酸化はどのようで あろうか。興味深いことに，分裂期特異的なヒストン $\mathrm{H} 3$ のリン酸化といら現象自体は保存されているが，染色体 上におけるリン酸化パターンには大きな違いが見られる. シロイヌナズナやタバコ BY-2 細胞では，染色体凝縮が 始まる前期においてセントロメア周辺領域で始まり, 免 疫染色像ではドット状のシグナルとして観察される(図 2A）。乙して, 後期において姉妹染色分体が分離すると, 染色分体全体に広がりながら消失する. 3 章で述べた ように，ヘスペラジンによってオーロラキナーゼを阻害 するとH3S10ph は顕著に減少する (図 2B)。シロイヌナ ズナ，BY-2 細胞ともに遅延染色体は観察されるが，染 色体凝縮といった染色体構造には異常は見られなかっ た (Kurihara et al. 2006, Demidov et al. 2009)ことより, 植物においてH3S10ph は染色体凝縮に重要ではない といえる(図2B).

ヒストンH3はSer10のほかに, Thr3, Thr11, Ser28 でも細胞分裂期特異的に少酸化される. ヒトにおいて, H3S28ph はH3S10ph 同様に染色体周縁領域全体で起 こる(図4A, C, 赤; Goto et al. 2002). H3T3ph は染色 体全体で起こるが，中期染色体をスライドガラスに展開 して免疫染色すると, セントロメア周辺領域に限定して 観察される(図4A, 緑; Dai et al. 2005)。H3T11phは 細胞分裂期を通してセントロメア周辺領域で起こる(図 4C, 緑; Preuss et al. 2003). リン酸化パターンの違いか らもわかるように，ヒストン $\mathrm{H} 3$ はとれぞれ異なる分裂期 キナーゼによってリン酸化されており，H3S10とH3S28 はAurora Bキナーゼ (Goto et al. 2002)，H3T3はハス ピンキナーゼ (Dai et al. 2005), H3T11はin vitroでし か確かめられていないが Dlk/ZIPキナーゼ (Preuss et al. 2003) によってリン酸化されている. 植物において もH3S28ph，H3T3ph，H3T11phは保存されているが， H3S10ph 同様に動物とは異なるリン酸化パターンを示 す. H3S28phはH3S10ph 同様セントロメア周辺領域で 起こるが，H3T3ph，H3T11phは染色体全体で起こる(図 4B, D; Kurihara et al. 2006, Houben et al. 2007). ヌク レオソームを構成しているヒストンタンパク質は生物間で 高度に保存されており，ヒストンH3では，ヒトとシロイヌ 
ナズナで比べると，135アミノ酸のうち4アミノ酸しか違 いはない，特に翻訳後修飾をうけるヒストンテール部分 は同一であり，H3リン酸化といった現象自体も保存さ れていながら，そのリン酸化パターンは動植物間で明 確に違っていることは興味深い.
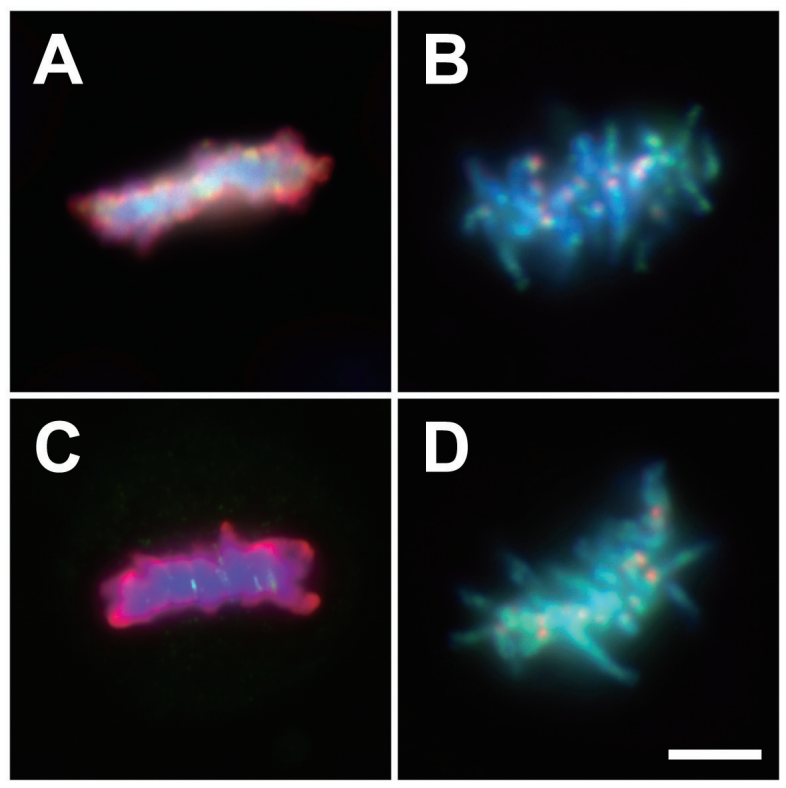

図4 動物 (ヒトHeLa 細胞) と植物 (タバコBY-2 細胞)におらる ヒストンH3リン酸化

(A，B）分裂中期における抗 $\mathrm{H} 3 \mathrm{~S} 28 \mathrm{ph}$ 抗体 (赤)，抗 H3T3ph抗体 (緑)を用いた免疫染色. DNAをDAPIで染色 した (青). HeLa細胞ではH3S28ph が染色体周縁領域に広 がり，H3T3phは比較的染色体内部にシグナルが観察される が(A)，BY-2 細胞ではH3S28ph がセントロメア周辺領域にドッ 卜状の, H3T3phが染色体全体にシグナルが観察される (B). (C，D) H3T11ph (緑) も HeLa 細胞 (C) とBY-2 細胞 (D) で同 様のパターンの違いを示すが，H3T3ph と比べて HeLa 細胞 においてセントロメア領域にシグナルが観察される $(\mathrm{C})$ ．スケー ルバーは $10 \mu \mathrm{m}$.

最近, 出芽酵母, アフリカツメガエル, ヒトにおいて, ヒストン H3 のリン酸化を介した分裂期キナーゼ制御の 新たなカスケードが報告され注目されている (Wang et al. 2010, Kelly et al. 2010, Yamagishi et al. 2010).2章 で述べたように，Aurora Bキナーゼは動原体における 張力を監視するために，インナーセントロメアに局在す ることが重要である. ハスピンキナーゼがまずインナー セントロメアにおいてH3T3をリン酸化する. 続いて, Aurora Bキナーゼと複合体を形成しているSurvivinと 呼ばれるタンパク質がその H3T3ph と結合することによつ て, Aurora Bキナーゼがインナーセントロメアに運ばれ， キナーゼ活性を発揮する (Wang et al. 2010, Kelly et al.
2010, Yamagishi et al. 2010).このようにヒストンH3リン 酸化は，それぞれ特異的な分裂期キナーゼによって， 適切な時期，適切な場所でリン酸化されることによって， 染色体構造ではなく，染色体動態を制御しているのか もしれない.

\section{植物における分裂期キナーゼ研究の現状}

ところで，リン酸化を介した種々のシグナル伝達系 は細胞増殖や環境応答などに重要な役割を担ってい る.ヒトでは約 500 遺伝子がセリン・スレオニンキナー ゼをコードしていると推定されているが (Manning et al. 2002)，植物においてはシロイヌナズナにおいて約 1,000 遺伝子 (Champion et al. 2004)，イネにおいては約 1,400 遺伝子 (Dardick et al. 2007) と，実に2倍にもおよぶキ ナーゼの存在が推定されている，植物において，核内 で働く多くのキナーゼが報告されているが，分裂期キ ナーゼの報告は驚くほど少ないのが現状である (Dahan et al. 2010) .

植物分裂期キナーゼとしてよく研究されている夕 ンパク質として, MAP (Mitogen-activated ptotein) キ ナーゼが挙げられる。 MAPキナーゼ（MAPK）は, MAPKキナーゼ (MAPKK)，MAPKキナーゼキナー ゼ (MAPKKK) とともにMAPK カスケードとよばれる情 報伝達経路を構成しており，このMAPKカスケードは 広く真核生物に保存される情報伝達経路であるが，植 物においても発生，細胞増殖，ホルモン応答，ストレ ス応答など多岐にわたつて働いている (Nakagami et al. 2005）。分裂期においては，NACK-PQR 経路とよば れるMAPKカスケードが，細胞質分裂を制御すること が明らかになってきている(Takahashi et al. 2004). タ バコにおいて，キネシン様タンパク質であるNACK1 と NACK2 がM期特異的に発現し，MAPKKKであ るNPK1 と結合することによってNPK1の活性とフラグ モプラスト中央部への局在を制御している (Nishihama et al. 2002). 活性化されたNPK1 MAPKKKはNQK1 MAPKKをリン酸化することによって活性化し，さらに NQK1 MAPKKはNRK1 MAPKを活性化する (Soyano et al. 2003). そしてNRK1 MAPKは微小管結合タン パク質MAP (microtubule-associated protein) である NtMAP65-1 をリン酸化することによって微小管束化活 性を低下させ，微小管の重合・脱重合を促進し，フラ グモプラストの拡大成長を促すことによって，細胞板形 
成を制御していると考えられている(Sasabe et al. 2006). またシロイヌナズナにおいても，NACK-PQR 経路が細 胞質分裂を制御していることが明らかになりつつある. HINKEL/AtNACK1 とSTUD/TETRASPORE/AtNACK2が NACK1, NACK2 (Nishihama et al. 2002, Strompen et al. 2002, Yang et al. 2003, Tanaka et al. 2004), ANP1, ANP2, ANP3がMAPKKKであるNPK1 (Nishihama et al. 1997, Krysan et al. 2002), MKK6/ANQが MAPKK であるNQK1 のオーソログとして同定されている(Soyano et al. 2003).さらに最近, GFP融合MKK6が細胞板 形成部位に局在し，in vitroにおいて精製MKK6が MPKの1つであるMPK4を少ン酸化すること（Takahashi et al. 2010), GFP融合 MPK4 も細胞板形成部位に 局在し, in vitroにおいて精製MPK4 は細胞質分裂 に関わるMAP65-3をリン酸化すること(Takahashi et al. 2010)，そしてそれぞれの変異体解析の結果から HINKEL/AtNACK1, ANPs, MKK6/ANQ, MPK4が シロイヌナズナにおけるNACK-PQR 経路を構成しており, 細胞板形成を制御していることが明らかにされつつある.

またシロイヌナズナにおいて, NIMA (never in mitosis, gene A) -related protein kinase 6 (NEK6)が，ア ルマジロリピートを持つキネシン様タンパク質と相互作 用して働くことが明らかとなっている (Sakai et al. 2008). NEK6の機能欠損変異体は表皮細胞の伸長方向の異 常を示し，またGFP融合 NEK6 は微小管上に局在し ており，微小管動態を制御することによって伸長方向 を制御することが示唆されている (Motose et al. 2008). NIMAキナーゼはコウジカビにおいて分裂期の開始に 必須であり，またヒストンH3 Ser10リン酸化能を有して いる(O’ Connell et al. 2003). 動物においては, 11 種 類あるうちの 4 種類の NEK が分裂期において中心体 の分離, 分裂期進行, 紡錘体形成に関わっているが (O’Regan et al. 2007)，シロイヌナズナNEK6の分裂期 における機能は未だ明らかではない。

Tousledキナーゼは葉や花の発生に重要なキナーゼ として同定され (Roe et al. 1993)，その後in vitroにお いてヒストン H3 のリン酸化能を持ち, G2 期後半から M 期, そして G1 期前半でキナーゼ活性が上昇することよ り (Ehsan et al. 2004)，分裂期においてなんらかの役割 を担っているとされたが，H3S10phにTousled は必要な いとの報告もあり (Wang et al. 2007)，その機能は未知 のままである.

\section{おわりに}

動物細胞と植物細胞の細胞分裂の様式には明確な 違いが見られるが，染色体動態を考えると今のところ大 きな違いは見られていない. 細胞分裂様式の違いは, 植物は細胞壁を持つといった動物との細胞構造の違い に起因寸るものであるが，遺伝情報の分配といった生 命の根幹に関わる染色体動態制御機構というものは生 物間で高度に保存されているのかもしれない，本稿で はシロイヌナズナとタバコのオーロラキナーゼを紹介し たが，配列情報をもとにオーロラキナーゼを探索する と, 被子植物, 裸子植物, シダ植物, コケ植物, 緑藻, 紅藻と広く植物に保存されていることがわかる(Demidov et al. 2005).このことからも，オーロラキナーゼを含む 分裂期キナーゼのさらなる研究から, 生物普遍的な染 色体動態制御機構が明らかにされていくこが期待され る.また，著者らはシロイヌナズナにおける八スピンキ ナーゼを現在同定しており (栗原ら, 投稿中), ヒストン H3リン酸化パターンが違うようにオーロラキナーゼ・八 スピンキナーゼが関わる植物特有の染色体動態制御機 構が見えてくるかもしれない.

\section{謝辞}

本総説は, 2010 年度植物形態学会奨励賞の受賞 研究の内容を元に執筆したものである. 本総説で紹介 した細胞分裂期における植物オーロラキナーゼの研究は, 日本学術振興会特別研究員として, 大阪大学大学院 工学研究科生命先端工学専攻でおこなったものである. ご指導・ご支援を頂いた福井希一教授，松永幸大准 教授をはじめとした研究室の方々にこの場を借りて深く 御礼申し上げたい.

\section{引用文献}

Adams, R. R., Maiato, H., Earnshaw, W.C., and Carmena, M. (2001) Essential roles of Drosophila inner centromere protein (INCENP) and aurora $B$ in histone $\mathrm{H} 3$ phosphorylation, metaphase chromosome alignment, kinetochore disjunction, and chromosome segregation. $J$ Cell Biol 153: 865-880.

Bradbury, E. M., Inglis, R. J., Matthews, H. R., and Sarner, N. (1973) Phosphorylation of very-lysine-rich histone in Physarum polycephalum. Correlation with chromosome condensation. Eur J Biochem 33: 131-139.

Carmena, M., Ruchaud, S., and Earnshaw, W. C. (2009) Making the Auroras glow: regulation of Aurora A and B kinase function by interacting proteins. Curr Opin Cell Biol 
21: 796-805.

Champion, A., Kreis, M., Mockaitis, K., Picaud, A., and Henry, Y. (2004) Arabidopsis kinome: after the casting. Funct Integr Genomics 4: 163-187.

Dahan, J., Wendehenne, D., Ranjeva, R., Pugin, A., and Bourque, S. (2010) Nuclear protein kinases: still enigmatic components in plant cell signalling. New Phytol 185: 355368.

Dai, J., Sultan, S., Taylor, S. S., and Higgins, J. M. (2005) The kinase haspin is required for mitotic histone $\mathrm{H} 3 \mathrm{Thr}$ 3 phosphorylation and normal metaphase chromosome alignment. Genes Dev 19: 472-488.

Dardick, C., Chen, J., Richter, T., Ouyang, S., and Ronald, P. (2007) The rice kinase database. A phylogenomic database for the rice kinome. Plant Physiol 143: 579-586.

Demidov, D., Hesse, S., Tewes, A., Rutten, T., Fuchs, J., Ashtiyani, R. K., Lein, S., Fischer, A., Reuter, G., and Houben, A. (2009) Auroral phosphorylation activity on histone $\mathrm{H} 3$ and its cross-talk with other post-translational histone modifications in Arabidopsis. Plant J 59: 221-230.

Demidov, D., Van Damme, D., Geelen, D., Blattner, F. R., and Houben, A. (2005) Identification and dynamics of two classes of aurora-like kinases in Arabidopsis and other plants. Plant Cell 17: 836-848.

Ehsan, H., Reichheld, J. P., Durfee, T., and Roe, J. L. (2004) TOUSLED kinase activity oscillates during the cell cycle and interacts with chromatin regulators. Plant Physiol 134: 1488-1499.

Goto, H., Yasui, Y., Nigg, E. A., and Inagaki, M. (2002) Aurora-B phosphorylates Histone $\mathrm{H} 3$ at serine 28 with regard to the mitotic chromosome condensation. Genes Cells 7: 11-17.

Gurley, L. R., Walters, R. A., and Tobey, R. A. (1975) Sequential phsophorylation of histone subfractions in the Chinese hamster cell cycle. J Biol Chem 250: 3936-3944.

Houben, A., Demidov, D., Caperta, A. D., Karimi, R., Agueci, F., and Vlasenko, L. (2007) Phosphorylation of histone H3 in plants--a dynamic affair. Biochim Biophys Acta 1769: 308315.

Hsu, J. Y., Sun, Z. W., Li, X., Reuben, M., Tatchell, K., Bishop, D. K., Grushcow, J. M., Brame, C. J., Caldwell, J. A., Hunt, D. F., Lin, R., Smith, M. M., and Allis, C. D. (2000) Mitotic phosphorylation of histone $\mathrm{H} 3$ is governed by Ipl1/aurora kinase and Glc7/PP1 phosphatase in budding yeast and nematodes. Cell 102: 279-291.

Kawabe, A., Matsunaga, S., Nakagawa, K., Kurihara, D., Yoneda, A., Hasezawa, S., Uchiyama, S., and Fukui, K. (2005) Characterization of plant Aurora kinases during mitosis. Plant Mol Biol 58: 1-13.

Kelly, A. E., Ghenoiu, C., Xue, J. Z., Zierhut, C., Kimura, H., and Funabiki, H. (2010) Survivin reads phosphorylated histone $\mathrm{H} 3$ threonine 3 to activate the mitotic kinase Aurora B. Science 330: 235-239.

Kouzarides, T. (2007) Chromatin modifications and their function. Cell 128: 693-705.

Krysan, P. J., Jester, P. J., Gottwald, J. R., and Sussman, M. R. (2002) An Arabidopsis mitogen-activated protein kinase kinase kinase gene family encodes essential positive regulators of cytokinesis. Plant Cell 14: 1109-1120.

Kurihara, D., Kawabe, A., Matsunaga, S., Nakagawa, K., Fujimoto, S., Uchiyama, S., and Fukui, K. (2007) Characterization of a splicing variant of plant Aurora kinase. Plant Cell Physiol 48: 369-374.

Kurihara, D., Matsunaga, S., Kawabe, A., Fujimoto, S., Noda, M., Uchiyama, S., and Fukui, K. (2006) Aurora kinase is required for chromosome segregation in tobacco BY-2 cells. Plant J 48: 572-580.

Kurihara, D., Matsunaga, S., Uchiyama, S., and Fukui, K. (2008) Live cell imaging reveals plant aurora kinase has dual roles during mitosis. Plant Cell Physiol 49: 12561261.

MacCallum, D. E., Losada, A., Kobayashi, R., and Hirano, T. (2002) ISWI remodeling complexes in Xenopus egg extracts: identification as major chromosomal components that are regulated by INCENP-aurora B. Mol Biol Cell 13: 25-39.

Manning, G., Whyte, D. B., Martinez, R., Hunter, T., and Sudarsanam, S. (2002) The protein kinase complement of the human genome. Science 298: 1912-1934.

Marks, D. B., Paik, W. K., and Borun, T. W. (1973) The relationship of histone phosphorylation to deoxyribonucleci acid replication and mitosis during the HeLa S-3 cell cycle. J Biol Chem 248: 5660-5667.

Motose, H., Tominaga, R., Wada, T., Sugiyama, M., and Watanabe, Y. (2008) A NIMA-related protein kinase suppresses ectopic outgrowth of epidermal cells through its kinase activity and the association with microtubules. Plant J 54: 829-844.

Musacchio, A., and Salmon, E. D. (2007) The spindle-assembly checkpoint in space and time. Nat Rev Mol Cell Biol 8: 379-393.

Nakagami, H., Pitzschke, A., and Hirt, H. (2005) Emerging MAP kinase pathways in plant stress signalling. Trends Plant Sci 10: 339-346.

Nishihama, R., Banno, H., Kawahara, E., Irie, K., and Machida, Y. (1997) Possible involvement of differential splicing in regulation of the activity of Arabidopsis ANP1 that is related to mitogen-activated protein kinase kinase kinases (MAPKKKs). Plant J 12: 39-48.

Nishihama, R., Soyano, T., Ishikawa, M., Araki, S., Tanaka, H., Asada, T., Irie, K., Ito, M., Terada, M., Banno, H., Yamazaki, Y., and Machida, Y. (2002) Expansion of the cell plate in plant cytokinesis requires a kinesin-like protein/ MAPKKK complex. Cell 109: 87-99.

O'Connell, M. J., Krien, M. J., and Hunter, T. (2003) Never say never. The NIMA-related protein kinases in mitotic control Trends Cell Biol 13: 221-228.

O'Regan, L., Blot, J., and Fry, A. M. (2007) Mitotic regulation by NIMA-related kinases. Cell Div 2: 25.

Preuss, U., Landsberg, G., and Scheidtmann, K. H. (2003) Novel mitosis-specific phosphorylation of histone $\mathrm{H} 3$ at Thr11 mediated by Dlk/ZIP kinase. Nucleic Acids Res 31: 878-885.

Roe, J. L., Rivin, C. J., Sessions, R. A., Feldmann, K. A., and 
Zambryski, P. C. (1993) The Tousled gene in A. thaliana encodes a protein kinase homolog that is required for leaf and flower development. Cell 75: 939-950.

Sakai, T., Honing, H., Nishioka, M., Uehara, Y., Takahashi, M., Fujisawa, N., Saji, K., Seki, M., Shinozaki, K., Jones, M. A., Smirnoff, N., Okada, K., and Wasteneys, G. O. (2008) Armadillo repeat-containing kinesins and a NIMA-related kinase are required for epidermal-cell morphogenesis in Arabidopsis. Plant J 53: 157-171.

Sasabe, M., Soyano, T., Takahashi, Y., Sonobe, S., Igarashi, H., Itoh, T.J., Hidaka, M., and Machida, Y. (2006) Phosphorylation of NtMAP65-1 by a MAP kinase downregulates its activity of microtubule bundling and stimulates progression of cytokinesis of tobacco cells. Genes Dev 20: 1004-1014.

Soyano, T., Nishihama, R., Morikiyo, K., Ishikawa, M., and Machida, Y. (2003) NQK1/NtMEK1 is a MAPKK that acts in the NPK1 MAPKKK-mediated MAPK cascade and is required for plant cytokinesis. Genes Dev 17: 1055-1067.

Strompen, G., El Kasmi, F., Richter, S., Lukowitz, W., Assaad, F. F., Jurgens, G., and Mayer, U. (2002) The Arabidopsis HINKEL gene encodes a kinesin-related protein involved in cytokinesis and is expressed in a cell cycle-dependent manner. Curr Biol 12: 153-158.

Takahashi, Y., Soyano, T., Kosetsu, K., Sasabe, M., and Machida, Y. (2010) HINKEL kinesin, ANP MAPKKKs and MKK6/ANQ MAPKK, which phosphorylates and activates MPK4 MAPK, constitute a pathway that is required for cytokinesis in Arabidopsis thaliana. Plant Cell Physiol 51: 1766-1776.

Takahashi, Y., Soyano, T., Sasabe, M., and Machida, Y. (2004) A MAP kinase cascade that controls plant cytokinesis. $J$ Biochem 136: 127-132.

Tanaka, H., Ishikawa, M., Kitamura, S., Takahashi, Y., Soyano, T., Machida, C., and Machida, Y. (2004) The AtNACK1/ HINKEL and STUD/TETRASPORE/AtNACK2 genes, which encode functionally redundant kinesins, are essential for cytokinesis in Arabidopsis. Genes Cells 9: 1199-1211.

Uchida, K. S., Takagaki, K., Kumada, K., Hirayama, Y., Noda, T., and Hirota, T. (2009) Kinetochore stretching inactivates the spindle assembly checkpoint. J Cell Biol 184: 383-390.

Wang, F., Dai, J., Daum, J. R., Niedzialkowska, E., Banerjee, B., Stukenberg, P. T., Gorbsky, G. J., and Higgins, J. M. (2010) Histone H3 Thr-3 phosphorylation by Haspin positions Aurora B at centromeres in mitosis. Science 330: 231-235.

Wang, Y., Liu, J., Xia, R., Wang, J. G., Shen, J., Cao, R., Hong, X. H., Zhu, J. K., and Gong, Z. Z. (2007) The protein kinase TOUSLED is required for maintenance of transcriptional gene silencing in Arabidopsis. EMBO Rep 8: 77-83.

Wei, Y., Yu, L., Bowen, J., Gorovsky, M. A., and Allis, C. D. (1999) Phosphorylation of histone H3 is required for proper chromosome condensation and segregation. Cell 97: 99109.

Yamagishi, Y., Honda, T., Tanno, Y., and Watanabe, Y. (2010) Two histone marks establish the inner centromere and chromosome bi-orientation. Science 330: 239-243.
Yang, C. Y., Spielman, M., Coles, J. P., Li, Y., Ghelani, S., Bourdon, V., Brown, R. C., Lemmon, B. E., Scott, R. J., and Dickinson, H. G. (2003) TETRASPORE encodes a kinesin required for male meiotic cytokinesis in Arabidopsis. Plant J 34: 229-240. 